\title{
Culture of pig embryos
}

\author{
R. M. Petters and K. D. Wells \\ Reproductive Physiology Research Laboratory, Department of Animal Science, North Carolina State \\ University, Raleigh, NC 27695-7621, USA
}

Pig embryos can be cultured using a number of different strategies including complex approaches like culture in vivo in a surrogate oviduct (rabbit, sheep, mouse), culture in mouse oviducts in organ culture, and co-culture of embryos with cells in addition to simple approaches like culture in defined media or salt solutions. Addition of serum to medium has been of particular importance where blastocyst development and hatching are required. Pig conceptuses (day 10-15), embryonic discs or cell lines derived from conceptuses can be cultured in complex media like Eagle's minimal essential medium or Dulbecco's modified Eagle's medium with serum, although embryonic discs can be cultured in the absence of serum. In contrast, early stage pig embryos (one-cell to blastocyst) are best cultured in simpler media such as those used for mouse embryos. The media that have been used are all relatively similar in composition. They contain salts and one or more energy sources such as glucose, lactate, or pyruvate with BSA as a macromolecular component. Early attempts to culture pig embryos were not very successful, but some embryos did develop to the blastocyst stage. More recent reports indicate a much higher rate of development with relatively little or no change in media composition. Some workers have reported improved development in medium lacking glucose, which is consistent with findings with laboratory animals such as hamsters. Glutamine can serve as the sole exogenous energy source in medium lacking glucose, lactate and pyruvate. Addition of taurine and hypotaurine to culture medium enhances development of pig embryos in vitro. We suggest, where possible, adoption of a standard medium that could be used by different laboratories and, perhaps, with different species. Use of one medium for different species would simplify experimental protocols, enhance studies of comparative embryonic physiology and metabolism, and expedite transfer of information obtained in different species.

\section{Introduction}

Considerable progress has been made in the culture of pig embryos since the comprehensive review of Davis (1985). It is now reasonable to expect that pig embryos can be cultured from the zygote to the blastocyst stage in vitro (Reed et al., 1992). At the same time, requirements for a particular experiment may require consideration of alternative methods for the culture of pig embryos. These may include in vivo culture in surrogate oviducts or in vitro culture in systems ranging from complex to simple or completely defined (Petters, 1992). Furthermore, the culture requirements of pig embryos at different stages may be distinctive and require special solutions. Applications in basic research and in biotechnology will benefit from the increased embryo viability associated with improved culture methods. This review documents current methods for pig embryo culture and indicates areas where further research is warranted. Other aspects are covered in Reed et al. (1992a). 


\section{In Vivo Culture}

The optimal culture environment for pig embryos is the pig reproductive tract itself. Early stage embryos, once removed and manipulated in some way, can be returned to the reproductive tract for short-term culture or for development to term (Day, 1979). The choice of recipients (donor female as recipient, synchronous versus asynchronous) is important and depends upon the experimental goals. If the embryos are to be recovered within a few days, recovery rate can be of some concern, but a high rate of embryo recovery should be expected.

Pig embryos have been cultured in the reproductive tracts of other species. Early stage pig embryos can develop to the morula and blastocyst stages following culture in the ligated oviducts of anoestrous sheep (Prather $e$ t al., 1991). The recovery rate from the sheep oviducts was high (83\%) and development of one- and two-cell embryos to morula or blastocyst stage was good (72\%). Transfer of embryos to recipient females ( $12 \mathrm{~h}$ asynchronous) resulted in offspring. In contrast, the ligated rabbit oviduct seems to be less suited for the culture of pig embryos (Herrmann and Holtz, 1985). Two-cell embryos developed well ( $95 \%$ normal development) in rabbit oviducts, whereas three- to four-cell embryos did not (24-45\%). With 48 h of culture, 146 of 170 two-cell embryos ( $86 \%$ ) developed beyond the four-cell stage. However, results following embryo transfer indicated a decline in viability if culture was for longer than $24 \mathrm{~h}$ in the rabbit oviduct. These results are in contrast to those for bovine or ovine embryos in rabbit oviducts where storage can be for a longer period (Hermann and Holtz, 1985).

The immature mouse oviduct can also be used for the culture of pig embryos. Morula and blastocyst stage embryos developed better in the mouse oviducts than in a complex culture medium (Ham's F-12, $10 \%$ fetal calf serum (FCS)) as judged by morphology and number of cells (Papaioannou and Ebert, 1988). However, the immature mouse oviduct could not support the development of pig zygotes beyond the four-cell stage (Ebert and Papaioannou, 1989).

The results cited above can be considered from a different viewpoint. What causes the different responses from pig embryos to different oviduct systems? The sheep oviduct appears to be permissive for pig embryo development, whereas the rabbit and mouse oviduct are not for certain cell stages. The pig oviduct itself only provides a suitable environment for development to the morula stage (Murray et al., 1971). Comparative studies of the oviduct environment could provide much information about early embryonic development which may lead to further improvement of pig embryo culture.

\section{Culture in Mouse Oviducts in Organ Culture and Co-culture with Cells}

The explanted mouse oviduct is a suitable culture environment for early embryos of a number of species (Biggers et al., 1962; Whittingham, 1968a, b, c; Minami et al., 1988). Pig embryos can develop from the one-cell to the blastocyst stage in the mouse oviduct in organ culture (Krisher et al., 1989b). Development of the pig embryos does not depend upon the presence of mouse embryos, which are included in the explant as a positive control (Krisher et al., 1989a). Approximately $78 \%$ of the embryos $(n=63)$ reached the morula or blastocyst stage in the mouse oviducts compared with $17-36 \%$ in modified Krebs' Ringer bicarbonate (mKRB) medium alone (Krisher et al., 1989a, b). These results have been confirmed by Williams et al. (1992); however, the overall rate of development was much lower in this study. Bovine embryos can also develop in mouse oviducts, but only when CZB medium (Chatot et al., 1989) is used to culture the explants (Sharif et al., 1991a, b, 1992). Attempts are being made to identify components in the mouse oviduct environment that are beneficial for embryo development (Minami et al., 1992).

Co-culture of pig embryos with cell monolayers including oviductal epithelial cells has been shown to be beneficial (Allen and Wright, 1984; White et al., 1989). However, this technique is not used extensively because of the relative success of defined media.

\section{Addition of Complex Biological Fluids to Culture Media}

Addition of oviductal fluid to culture medium enhances the in vitro development of one- and two-cell pig embryos (Archibong et al., 1989). Such fluid is not readily available for routine embryo culture 
experiments so it has not been used extensively. Pig oviductal fluid has been shown to contain insulinlike growth factor I (IGF-I) and IGF-II (Wiseman et al., 1992). Dilution of culture medium with oviductal fluid results in a predictable dilution of certain culture medium ingredients that are present at lower concentrations in oviductal fluid (Nichol et al., 1992).

Serum supplementation of pig embryo culture media is best discussed by referring to results with different stage embryos. Early stage embryos (one to eight cells) are most often cultured in media using BSA as a protein supplement. However, some studies have used serum supplementation during these stages. Niemann et al. (1983) reported the use of $10 \%$ heat-inactivated lamb serum with Krebs Ringer bicarbonate medium (KRB), although development in the absence of lamb serum was not assessed. This medium worked well for the culture of single blastomeres from eight-cell embryos when combined with an extracellular matrix of fibronectin (Saito and Niemann, 1991). Offspring were produced from single blastomeres that were cultured in vitro for $24 \mathrm{~h}$ before embryo transfer. Wollenberg et al. (1990) reported that addition of $20 \%$ heat-inactivated bull serum to phosphate-buffered saline (PBS) supported the development of two- to eight-cell pig embryos to the hatched blastocyst stage. In this report, it is not possible to determine whether the development of two-cell embryos was supported by this medium or whether only four-cell stage or greater developed. It is not clear whether previous reports from the same group (Herrmann and Holtz, 1981; Herrmann et al., 1981) used PBS also. Furthermore, the earlier reports indicated much lower rates of development with the same medium. For a historical account of repeatability problems, see Davis (1985).

The beneficial effect of serum (fetal calf, FCS or lamb, LS) on pig morulae or blastocysts can be traced to Robl and Davis (1981). Morulae cultured to blastocyst in modified KRB (mKRB) medium hatched only in the presence of serum (Robl and Davis, 1981; Rosenkrans et al., 1989). In another study, hatching did occur in the absence of serum, but at a reduced rate (Meyen et al., 1989). Dialysis of FCS apparently removed a factor that is important for cell division, but factors important for blastocyst expansion were not affected. Serum was also shown to support the development of later stage blastocysts (Robl and Davis, 1981). Day 8 blastocysts grew well over a 48 h period when KRB medium was supplemented with sheep serum or fetal calf serum. In this study, no attachment of the blastocysts to the dish occurred. Day 10 blastocysts grew only if they appeared developmentally similar to the day 8 embryos. Day 12 embryos, which were elongated and wrinkled in appearance, did not survive even for $24 \mathrm{~h}$.

Pig conceptuses (days 10-15) have been cultured in vitro for up to $30 \mathrm{~h}$ for certain biochemical analyses (Harney et al., 1990). The method used was that of Godkin et al. (1982) which uses Eagle's minimal essential medium (MEM) without protein supplementation. Documentation of cell viability was based on a linear release of radioactively labelled proteins from certain day 16 conceptuses over the period of $4-24 \mathrm{~h}$ of culture. Primary cell cultures established from day 14 and day 16 pig conceptuses (MEM plus $15 \%$ FCS) resulted in large, free-floating spheres as well as confluent cell cultures (Godkin et al., 1985). These cultures did not produce the same proteins as are found in the short-term cultures. It was suggested that the trophoblast cells did not survive well in culture. The formation of vesicles was also noted by Allen and Wright (1985) using MEM plus $10 \%$ FCS. Vesicles were formed only when cells were enzymatically dispersed from day 12-15 blastocysts, not from day 10 and 11 blastocysts. The hypothesis is that these vesicles are formed from embryonic disc material rather than from trophoblast cells.

Silcox and Johnson (1988) reported the culture of day 13 porcine embryonic discs in DMEM (Dulbecco's modified Eagle's) plus 10\% newborn bovine serum. Vesicles formed during the first $24 \mathrm{~h}$ of culture. These explants could be cultured for up to 10 days with a number developing pulsating tissue implying mesoderm differentiation. Estrada et al. (1991) cultured embryonic discs in DMEM without serum and demonstrated that IGF-I stimulated protein synthesis in vitro, suggesting a physiological role for the IGF found in oviductal fluid.

\section{Culture in Defined Media}

Research with laboratory animals, such as mice and hamsters, has been very important for pig embryo culture. The formulations used for pig embryo culture and base media used first with mouse embryos are 
shown (Table 1). In preparing this table, we noted a number of apparent mistakes in medium formulation tables. Medium formulations should therefore be evaluated from the original reference.

Research with laboratory animals such as hamsters has influenced pig embryo culture. Hamster embryos are very difficult to culture and in vitro developmental 'blocks' occur at the two-cell and eightcell stages. Bavister and co-workers have developed a culture medium for hamster embryos. Among the concepts that came from research with hamster embryos was that glucose and phosphate are inhibitory and cause the in vitro developmental blocks (Schini and Bavister, 1988b; Seshagiri and Bavister, 1989a, b; Seshagiri and Bavister, 1991). This concept has been found to be important for the in vitro culture of embryos from mice (Chatot et al., 1989), rats (Reed et al., 1992b), cattle (Ellington et al., 1990; Moore and Bondioli, 1993) and pigs (Petters et al., 1990; Youngs and McGinnis, 1990; Misener et al., 1991).

In our own laboratory, experiments were performed that resulted in a number of modifications to a culture medium for pig embryos. Pig embryos can develop from the one-cell stage using glutamine or glucose as their sole exogenous energy source (Petters et al., 1990). Glucose alone was not inhibitory. However, the interaction of glucose and phosphate was statistically significant. Other workers have reported favourable results either in the presence (Petters and Reed, 1991; Beckmann and Day, 1993; French et al., 1993) or absence (Misener et al., 1991; Youngs and McGinnis, 1990; Youngs et al., 1993) of glucose. Recent reports of the use of Whitten's medium (Beckmann and Day, 1993; French et al., 1993) have used the same modification of Whitten's formulation (Whitten and Biggers, 1968) as reported by Wright and co-workers (Wright, 1977; Linder and Wright, 1978; Menino and Wright, 1982). However, the more recent reports indicate a much higher rate of development with this medium.

High levels of embryonic development have been obtained with a medium designated NCSU-23, containing taurine and hypotaurine (Fig. 1 and Petters and Reed, 1991; Reed et al., 1992). Recently, workers in other laboratories have successfully used NCSU-23 for the in vitro culture of pig embryos (Illera ef al., 1992; Torres and Rath, 1992). Three media have been tested in our laboratory: a modified Whitten's medium with glucose $\left(5.56 \mathrm{mmol}^{-1}\right)$ and high BSA (1.5\%); a modified Whitten's medium lacking glucose and with $0.4 \%$ BSA; and NCSU-23 medium (see Table 1 for formulations). These findings (Table 2), although limited, are interesting. First, these results are consistent with those of Youngs and McGinnis (1990) who found better development of pig embryos in the absence of glucose when using a Whitten's medium. NCSU-23 contains glucose and has a higher $\mathrm{NaCl}$ concentration than Whitten's medium, yet the proportion of embryos developing to the blastocyst stage was similar to that in Whitten's medium without glucose.

In vitro culture of early stage pig embryos is quite feasible as has been demonstrated by Petters $e t$ al. (1990); Petters and Reed (1991); Reed et al. (1992); Youngs and McGinnis (1990); Youngs et al. (1993); Misener et al. (1991); Hagen et al. (1991) and Beckmann and Day (1993). Further considerations of in vitro culture of pig embryos can be best considered by a discussion of embryo metabolism.

\section{Embryo Metabolism and Culture In Vitro}

\section{Energy sources}

Oxaloacetate, phosphoenolpyruvate, pyruvate or lactate can be used as the exclusive energy source by early cleavage stage mouse embryos (Brinster, 1965b). Lactate and pyruvate are generally included in media formulations and lactate is thought to be required for optimal development (Biggers, 1987). Lactate inhibits porcine embryo development (Davis and Day, 1978; Davis, 1985; Stone et al., 1984) and neither lactate nor pyruvate is required for pig embryo development (Petters et al., 1990; Petters and Reed, 1991). All experiments that have been interpreted to demonstrate an inhibitory effect of lactate on pig embryos have been performed in the presence of glucose. Since lactate and pyruvate are included in all mouse embryo culture media, the inhibitory effect of glucose has been described only in the presence of lactate (Chatot et al., 1989). Glucose has been added or deleted in the presence of lactate in mice and interpreted to be inhibitory, whereas lactate was deleted or included in the presence of glucose in pigs and interpreted to be inhibitory. The inhibitory treatment is the same for both species - glucose plus lactate. Recently, glucose has been interpreted to be inhibitory in pig (Youngs and McGinnis, 1990; Misener et al., 1991), but again the inhibitory treatment contained lactate and glucose. 


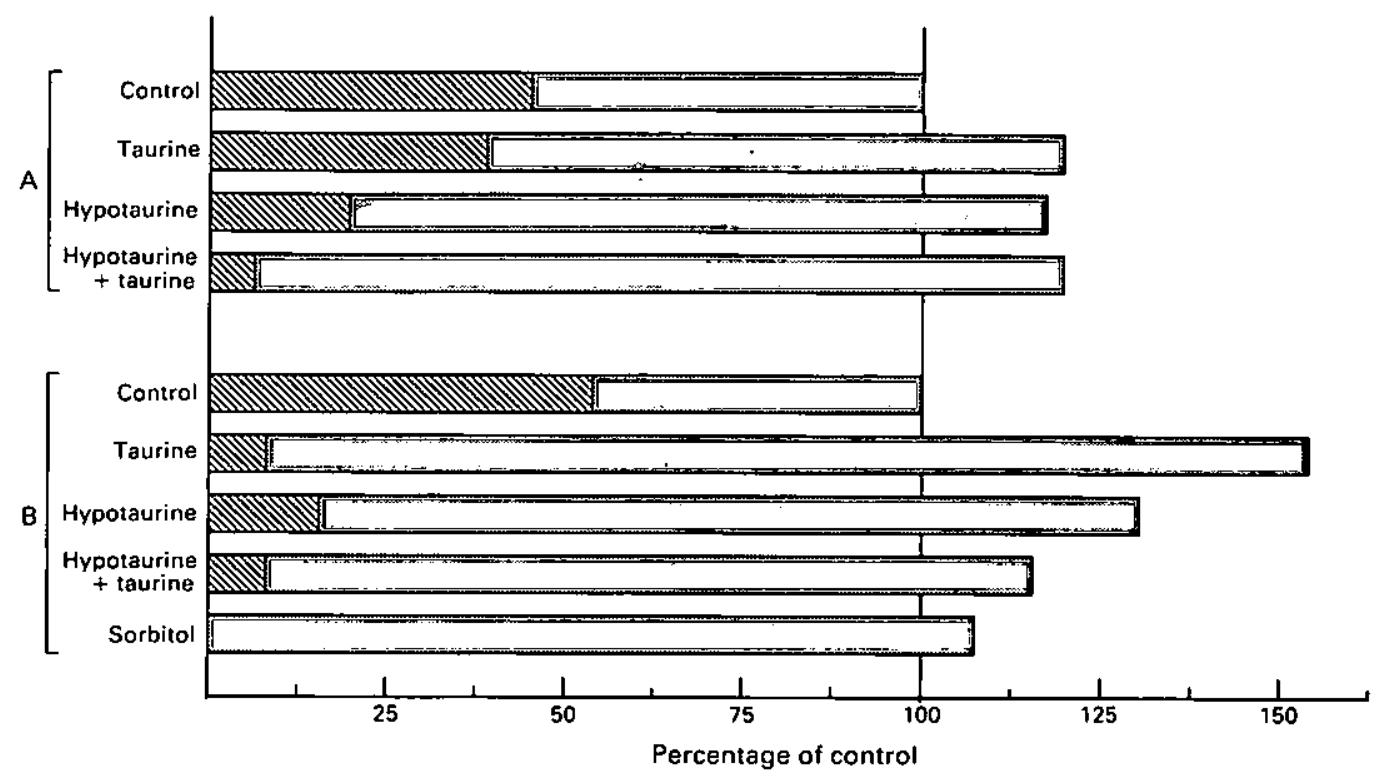

Fig. 1. Development of one- or two-cell pig embryos in media with or without taurine and hypotaurine: $(\mathbb{D})$ morula; (回) blastocyst. Data from two experiments (A and B) are displayed in this figure. Treatment with hypotaurine and taurine is medium NCSU-23 (see Table 1 for composition). Treatment with sorbitol is as in formulation of medium NCSU-37 (Table 1). Data are shown as percentage of control. For experiment A, 38-44 embryos were cultured in each treatment; for experiment B, 22 embryos were cultured in each treatment (Petters, 1992).

The Crabtree effect (Crabtree, 1929) has been proposed as the mechanism by which glucose exhibits its negative effect on preimplantation embryo development in hamsters (Seshagiri and Bavister, 1991) and it has been suggested that this occurs in pigs (Beckmann and Day, 1993). As reviewed by Koobs (1972), the Crabtree effect involves the depletion of phosphate (and perhaps adenosine diphosphate, ADP) in the presence of hexoses. The effect is caused by an overabundance of glycolytic enzymes (primarily hexokinase) and can be alleviated by the addition of phosphate. Since phosphate enhances the inhibitory effect of glucose in pig embryos (Petters et al., 1990), this effect is probably not a Crabtree effect, as the addition of phosphate would be expected to alleviate the effect, not enhance it. However, similar data have been interpreted as the Crabtree effect in hamsters (Schini and Bavister, 1988b). In the hamster the phosphate-glucose interaction inhibits respiration as is the case for glucose alone in the Crabtree effect (Seshagiri and Bavister, 1991).

The low oxygen environment preferred by embryos and some cancer cells demonstrates a similarity that may be related to metabolism. The Pasteur effect describes the differential rates of glycolysis under aerobic and anaerobic conditions. For example, anaerobic glycolysis can be four times faster than aerobic glycolysis (Wu and Racker, 1959). Koobs (1972) suggests that the Pasteur effect (anaerobic glycolysis running faster than aerobic) and the Crabtree effect (depression of respiration via overactive hexokinase and abundant glucose) may be caused by the same mechanism - insufficient phosphate to simultaneously satisfy glycolysis and oxidative phosphorylation. In the Pasteur effect, mitochondria out-compete glycolysis for phosphate in the presence of oxygen, whereas in the Crabtree effect there is an overabundance of glycolytic enzymes. Nevertheless, in both cases, addition of phosphate to the media is the cure - rather than the cause. Pigs and hamsters may provide a unique opportunity to study the control of glycolysis and respiration. The Crabtee effect, the Pasteur effect, and the phosphate-glucose effect observed by Bavister in hamsters (Schini and Bavister, 1988b; which appears to be present in the pig; Petters et al., 1990; Youngs and McGinnis, 1990) are closely related and reflect the metabolic interconnections between glycolysis and respiration. 


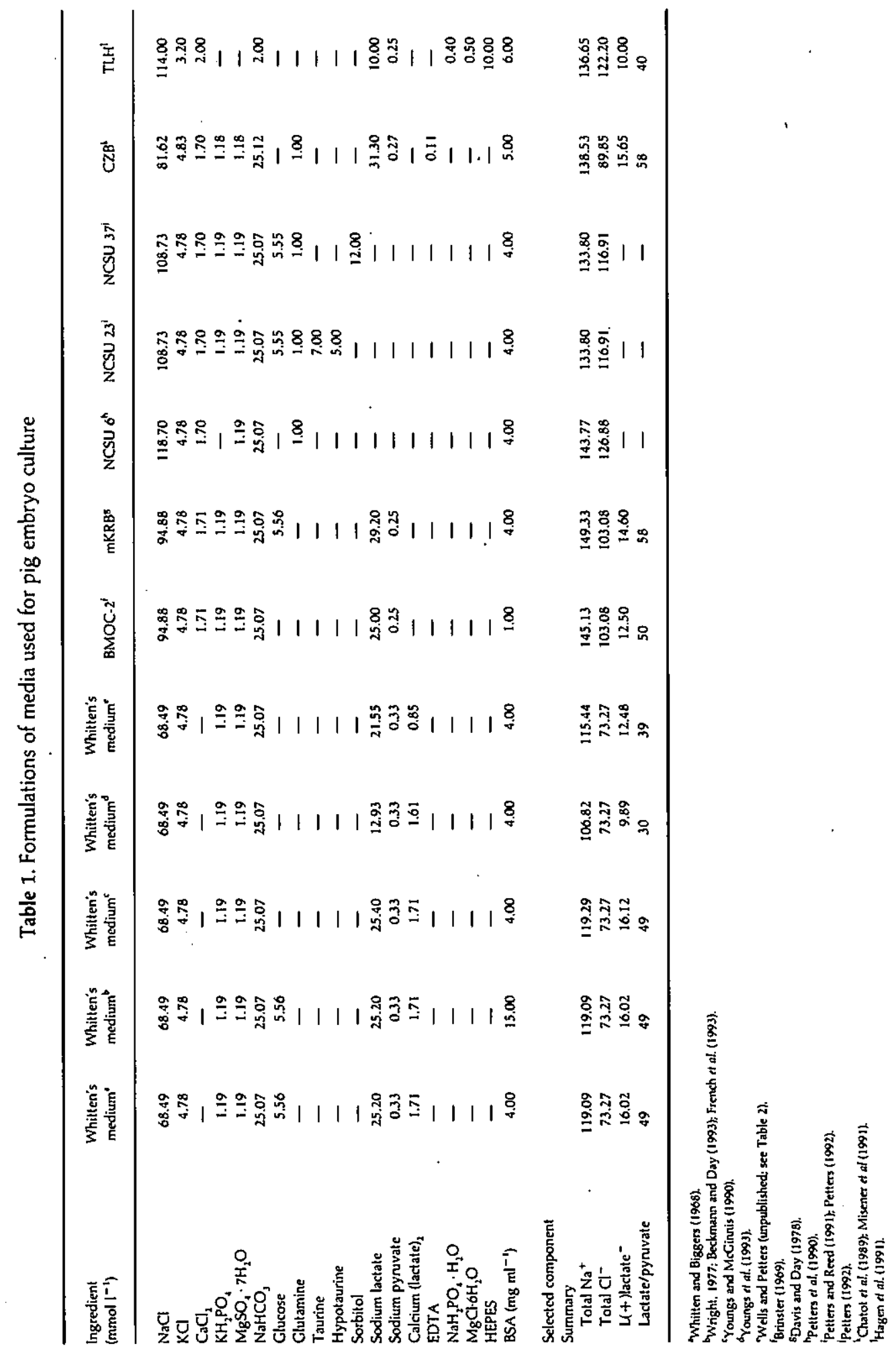


Table 2. Development of one- and two-cell pig embryos in three media

\begin{tabular}{|c|c|c|c|c|c|}
\hline Medium & $n$ & Degenerate & Cleavage & Morula & Blastocyst (\%) \\
\hline $\begin{array}{c}\mathrm{mWM}^{*}+\text { Glucose }+ \\
1.5 \% \text { BSA }\end{array}$ & ${ }^{\prime} 28$ & 5 & 8 & 3 & $12(43)^{2}$ \\
\hline $\begin{array}{l}\mathrm{mWM}^{*} \text { Glucose }+ \\
0.4 \% \text { BSA }\end{array}$ & 28 & 1 & 3 & 2 & $22(75)^{b}$ \\
\hline NCSU $23 \dagger$ & 28 & 0 & 5 & 3 & $20(71)^{b}$ \\
\hline
\end{tabular}

Values with different superscripts are statistically different $(P<0.05)$.

mWM: modified Whitten's medium.

"Wells and Petters (unpublished; see footnote e, Table 1).

†Petters and Reed (1991): Petters (1992).

In mice, it has been suggested that the glucose effect depends on $\mathrm{NaCl}$ (Lawitts and Biggers, 1991a). The Crabtree effect would not lead to a prediction of $\mathrm{NaCl}$ dependency. Glucose inhibition of development of pig embryos has been demonstrated in modified Whitten's media with relatively low $\mathrm{NaCl}$ (Youngs and McGinnis, 1990) and in CZB which also has relatively low $\mathrm{NaCl}$ (Misener et al., 1991). In some types of cell, glucose transport into the cell is $\mathrm{Na}^{+}$-dependent which could connect the Crabtree effect with $\mathrm{Na}^{+}$dependency. However, this is probably not the case in preimplantation embryos since $\mathrm{Na}^{+}$-dependent glucose transport could not be detected (Powers and Tupper, 1977; Gardner and Leese, 1988). The nature of glucose metabolism in pig embryos has recently been described (Flood and Wiebold, 1988).

\section{Amino acids - energy, nitrogen and toxicity}

As in mice (Chatot et al, 1990; Lawitts and Biggers, 1992), glutamine has been demonstrated to enhance in vitro embryo development in pigs (Petters et al., 1990). Glucose or glutamine was shown to support embryo development as the sole energy source from the one-cell stage to the blastocyst stage.

Mice and pigs can develop to the blastocyst stage in media that contain no free amino acids. It has been proposed (Gardner and Lane, 1993) that amino acids could serve as osmoregulators/ osmoprotectants, $\mathrm{pH}$ regulators, and energy sources in preimplantation embryos. The amino acids found to be beneficial for embryo development in hamsters (Schini and Bavister, 1988a) and mice (Gardner and Lane, 1993) parallel those that have been found to be abundant in mouse oocytes (Schultz et al., 1981) and rabbit oviductal fluid (Miller and Schultz, 1987). Only recently has the use of amino acids in murine embryo culture media shown promise (Gardner and Lane, 1993). Mouse embryos do possess specific transport mechanisms for amino acids throughout the preimplantation period (Van Winkle, 1988). Likewise, amino acid transporters are beginning to be described for pigs (Prather et al., 1993).

Gardner and Lane (1993) suggest that any detrimental effect of amino acids could be attributed to ammonia production from the spontaneous degradation of amino acids during embryo culture as well as metabolism of endogenous nitrogen sources. Murine embryos used in these experiments appear to have an extreme sensitivity to ammonia which could account for observations that the culture volume and the presence or absence of an oil overlay can affect embryo development (Menino and Wright, 1982). The apparent difference in amino acid requirements between the hamster model and the mouse and pig may be explained by the inability of the hamster embryo to maintain endogenous amino acid pools (Schini and Bavister, 1988a) and could explain the benefit of culturing in volumes of less than one microlitre when no amino acids are present. Again, different responses to manipulation of culture conditions are not necessarily indicative of metabolic differences. Under permissive conditions, amino acids other than glutamine may therefore prove to be beneficial in pigs though not required. Such benefits have been described for blastocyst expansion (Rosenkrans et al., 1989; Gardner and Lane, 1993). 


\section{Osmolarity}

The mouse model was used to demonstrate that a reduction in media osmolarity by reducing $\mathrm{NaCl}$ enhances embryo development (Lawitts and Biggers, 1991a, b). Likewise, addition of components known to have osmoprotectant effects against high $\mathrm{NaCl}$ in other systems also enhances development (Biggers et al. 1993). Modified Whitten's medium, (mWM) which has been used to support development of pig embryos to the blastocyst stage (Wright, 1977; Menino and Wright, 1982; Menino et al., 1989; Beckmann and Day, 1993), has a much lower $\mathrm{NaCl}$ concentration than does modified Krebs Ringer bicarbonate (mKRB; Davis and Day, 1978). However, culture media for pig embryos with relatively high $\mathrm{NaCl}$ can support development (Petters ef al., 1990). It must also be noted that upon addition of taurine, a potential osmoprotectant, embryo development was improved (Fig. 1; Petters and Reed, 1991). Lawitts and Biggers (1991b) suggested that high $\mathrm{Cl}^{-}$may be the detrimental ion in the mouse system. The media used by Petters et al. (1990) had slightly higher $\mathrm{Na}^{+}$than did $\mathrm{mWM}$ but much higher $\mathrm{Cl}^{-}$(see Table 1) which would lend credence to the hypothesis that $\mathrm{Na}^{+}$is the more detrimental ion in $\mathrm{NaCl}$.

Recently, the effect of osmolarity and ionic conditions was addressed in pigs (Beckmann and Day, 1993). A series of experiments was performed by adding ( $\mathrm{mKRB}$ ) or deleting ( $\mathrm{mWM}$ ) water in the media preparations. The osmolarity of the diluted mKRB was also adjusted back to undiluted values by the addition of sorbitol as an osmotic balance and similarly sorbitol was used to adjust the osmolarity of undiluted mWM to the level of undiluted mKRB. The results were interpreted to demonstrate that $\mathrm{Na}^{+}$ concentration and not necessarily osmolarity had a negative effect on development in vitro. This conclusion could be supported by Galvin et al. (1993) and by research with mouse embryos (Lawitts and Biggers, 1991a, b). However, the results are difficult to interpret because when modifying osmolarity with the volume of solvent, all media component concentrations are altered - including those that have been considered inhibitory. We used media based on the NCSU-23 formulation with reduced $\mathrm{NaCl}$ $\left(68 \mathrm{mmol} \mathrm{I}^{-1}\right.$; concentration used in Beckmann and Day, 1993). In those treatments with reduced $\mathrm{NaCl}$, pig embryo development was extremely low ( $n=32 ; 3 \%$ morula or blastocyst), whereas embryos developed well in media with higher $\mathrm{NaCl}$ concentration (109 mmol $\mathrm{l}^{-1} ; n=31 ; 84 \%$ morula or blastocyst). These data may reflect a lower limit of permissible $\mathrm{Na}^{+}$concentration or osmolarity.

The dilution of mKRB and readjustment of osmolarity with sorbitol produced a media that supported development of $100 \%$ of the one- and two-cell embryos to the morula or blastocyst stage (Beckmann and Day, 1993). The addition of sorbitol to murine embryo culture media can enhance development and accelerate compaction, blastocyst expansion and hatching (Wells et al., 1992). This information further complicates the interpretation of these experiments (Beckmann and Day, 1993), as a basic assumption was that sorbitol is an inert osmolyte. Whether sorbitol can cross the cell membrane or can be metabolized at all by pig embryos is unknown. However, it is known that intracellular concentrations of sorbitol increase in glucose sensitive cell types in response to glucose in the media (Hod et al., 1986; Eriksson et al., 1989; DelMonte et al., 1991; Nakamura et al., 1992) and in other cell types in response to osmotic stress of high $\mathrm{NaCl}$ (Bagnasco et al., 1987). Data are therefore available that provide precedence for a role of sorbitol in both glucose sensitivity and osmotic stress or high $\mathrm{Na}^{+}$which brings the assumption that sorbitol is inert into question.

\section{Universal Basal (UB) Medium}

There are many advantages to having a medium that can be easily compounded and used for a number of species. Use of such a medium will help standardize work between laboratories and allow studies of comparative embryo physiology. The medium, universal basal (UB) medium, is designed to provide a common starting point for embryo culture experiments in different species (Table 3). The formulation of this medium was based on recent research on oviductal fluid, many of the findings reviewed above on pig embryo culture and media used in other systems. The rationale for the inclusion and amount of each ingredient of the medium is discussed below.

The osmolarity chosen for UB was based on osmolarities of media currently in use and the optimum determined by Brinster (1965a) for mice. The actual $\mathrm{NaCl}$ concentration (nearly that of $\mathrm{CZB}$ ) is intermediate and was modified to balance $\mathrm{Na}^{+}$to that of Whitten's medium (Whitten and Biggers, 1968). KCl 
Table 3. Universal basal (UB) medium formulation

\begin{tabular}{|c|c|}
\hline UB - first formulation & $\left(\mathrm{mmol} 1^{-1}\right)$ \\
\hline \multicolumn{2}{|l|}{ Base Medium } \\
\hline $\mathrm{NaCl}$ & 80.42 \\
\hline $\mathrm{KCl}$ & 5.36 \\
\hline $\mathrm{MgSO}_{4} \cdot 7 \mathrm{H}_{2} \mathrm{O}$ & 1.06 \\
\hline $\mathrm{NaHCO}_{3}$ & 25.00 \\
\hline Sodium DC lactate & 12.08 \\
\hline Sodium pyruvate & 0.18 \\
\hline $\mathrm{L}(+) \mathrm{Ca}$ (lactate $)_{2}$ & 2.00 \\
\hline Glutamine & 1.03 \\
\hline \multicolumn{2}{|l|}{ Additives } \\
\hline Taurine & 7.03 \\
\hline Hypotaurine & 5.04 \\
\hline Sorbitol & 7.14 \\
\hline Sodium acetate & 0.49 \\
\hline Sodium aspartate & 1.93 \\
\hline Glycine & 7.06 \\
\hline Glutamate $\mathrm{HCl}$ & 0.98 \\
\hline BSA & $0.4 \%$ \\
\hline \multicolumn{2}{|c|}{ Selected component summary } \\
\hline $\mathrm{Na}^{+}$ & 118.17 \\
\hline $\mathrm{Cl}^{-}$ & 86.76 \\
\hline $\mathrm{L}(+)$ lactate & 10.50 \\
\hline $\mathbf{L}(+)$ lactate/pyruvate & 55 \\
\hline
\end{tabular}

was also increased in response to the finding of Biggers et al. (1993) that the $\mathrm{K}^{+}: \mathrm{Na}^{+}$ratio can be altered intracellularly under stress conditions, but total $\mathrm{K}^{+}$was not significantly altered since potassium phosphate was deleted. Phosphate was deleted as suggested by Schini and Bavister (1988a) for hamsters and Lawitts and Biggers (1991b) for mice and supported by data of Petters et al. (1990) which indicated that phosphate was not necessary for pig embryo development. The calcium concentration was increased based on data from oviduct secretions (Hamner and Fox, 1969) and the concentration used in hamster medium (Schini and Bavister, 1988a). The concentration for $L(+)$ lactate was decreased based on measurements of pig (Nichol et al., 1992) and rabbit (Holmdahl and Mastroianni, 1965) oviductal fluid and data from Youngs et al. (1993) with pig embryo development at lower lactate concentrations. It is still near the optimal value of lactate for mouse embryo development (Brinster, 1965b). The pyruvate concentration was based on measurements in pig (Nichol et al., 1992) and rabbit (Hamner and Fox, 1969) oviduct and is near the optimum concentration found by Brinster (1965b). Glutamine was included on the basis of data in mice (Chatot et al., 1990), hamsters (Schini and Bavister, 1988a), and pigs (Petters et al., 1990). Other components to be considered as additives would include: glucose, fructose, acetate; citrate and malate, since they can be used as the exclusive energy source by eight-cell mouse embryos (Brinster, 1969); hypotaurine and taurine owing to their benefit in hamsters (Barnett and Bavister, 1992), mice (Eppig et al., 1990), pigs (Petters and Reed, 1991) and rabbits ( $\mathrm{Li}$ et al., 1993); amino acids for reasons indicated above; sorbitol for its benefit in mice (Wells et al., 1992) and possibly pigs (Beckmann and Day, 1993); betaine for its osmotic protection (Biggers et al., 1993); and EDTA for its benefits in mice (Fissore et al., 1989) and it may allow the replacement of BSA with polyvinylalcohol (PVA; Youngs et al., 1991).

We have recently tested the formulation in Table 3 (UB-first formulation) on one-cell $(n=11,91 \%$ blastocyst) and four-cell pig embryos ( $n=31,94 \%$ blastocyst). Experiments testing this formulation in 
other species are in progress. The additional amino acids chosen for this first formulation were based on those included in HECM-1 (Schini and Bavister, 1988a) and the experiments of Gardner and Lane (1993). The amount chosen was the lower concentration of a comparison of HECM and oviductal fluid. The other additives included are based on the above justification and the concentration used was based on previous experiments - taurine (Schini and Bavister, 1988a; Eppig et al., 1990; Petters and Reed, 1991; Li et al., 1993), hypotaurine (Petters and Reed, 1991; Barnett and Bavister, 1992), sorbitol (Wells et al., 1992) and acetate (Carney and Bavister, 1987; Moore and Bondioli, 1993). It must be reiterated that UB media is suggested as a starting point and the optimum additives and their concentration would be determined for each species. It is also suggested that adjustment of $\mathrm{NaCl}$ be considered when additives in the form of a sodium salt are used.

\section{Conclusion}

The culture of preimplantation pig embryos is now sufficiently efficient for most laboratory and agricultural applications with current embryo culture media. The above discussion illustrates, however, that information on the nature of embryo culture requirements is limited. Why is embryo development in vitro so poor in media with $\mathrm{Na}^{+}$levels found in oviduct secretions? What are the ionic conditions most suited for embryo development? What are the optimum energy substrates? Are these questions even relevant in vitro and are there optimum concentrations for media components? To understand the intricacies of early embryo development and the role of the oviductal environment, an in vitro model must first be developed. Although embryo survival is high in vitro, the culture conditions do not model the conditions in vivo. Some oviductal fluid components may be found to be incidental simply owing to the nature of their origin (plasma and interstitial fluid). Other components may be found that allow the embryo to develop in the presence of components which would otherwise be detrimental, whereas other factors will be identified, the presence of which is specifically required for metabolic use by the embryo. More information is needed on oviductal secretions and the metabolism of preimplantation embryos to understand early development. We have suggested the advantages in attempting to develop a universal basal medium so that information gained in each species may be more easily evaluated in other species. Such a system would aid the study of reproduction and will become essential for the use of culture research in less studied species - especially those that are endangered.

\section{References}

Allen RL, and Wright RW, Jr (1984) in vitro development of porcine embryos in coculture with endometrial cell monolayers or culture supernatants jounal of Animal Science 59 1657-1661

Allen RL and Wright RW, Jr (1985) Observations on the in vitro formation, development and differentiation of trilaminar vesicles formed from enzymatically dispersed porcine blastocysts Theriogenology 23 333-345

Archibong AE, Petters RM and Johnson BH (1989) Development of porcine embryos from one- and two-cell stages to blastocysts in culture medium supplemented with porcine oviductal fuid Biology of Reproduction 41 1076-1083

Bagnasco SM, Uchida S, Balaban RS, Kador PF and Burg MB (1987) Induction of aldose reductase and sorbitol in renal inner medullary cells by elevated extracellular $\mathrm{NaCl}$ Proceedings of the National Academy of Sciences USA 84 1718-1720

Barnett DK and Bavister BD (I992) Hypotaurine requirement for in vitro development of golden hamster one-cell embryos into morulae and blastocysts, and production of term offspring from in vitro-fertilized ova Biology of Reproduction $47 \quad 297-304$
Beckmann $1 S$ and Day BN (1993) Effects of media $\mathrm{NaCl}$ concentration and osmolarity on the culture of early-stage porcine embryos and the viability of embryos cultured in a selected superior medium Theriogenology $39611-622$

Biggers JD (1987) Pioneering mammalian embryo culture. In The Mammalian Preimplantation Embryo pP 1-22 Ed. BD Bavister. Plenum Press, New York

Biggers JD, Gwatkin RBL, and Brinster RL (1962) Development of mouse embryos in organ cultures of fallopian tubes on a chemically defined medium Nature 194 747-749

Biggers JD, Lawitts, JA and Lechene CP (1993) The protective action of betaine on the deleterious effects of $\mathrm{NaCl}$ on preimplantation mouse embryos in vitro Molecular Reproduction and Development 34 380-390

Brinster RL (1965a) Studies on the development of mouse embryos in vitro. I. The effect of osmolarity and hydrogen ion concentration Joumal of Experimental Zoology 158 49-58

Brinster RL (1965b) Studies on the development of mouse embryos in vitro. II. The effect of energy source joumal of Experimental Zoology 158 59-68 
Brinster RL (1965c) Studies on the development of mouse embryos in vitro. IV. Interaction of energy sources Joumal of Reproduction and Fertility 10 227-240

Brinster RL, (1969) Mammalian embryo culture. In The Mammalian Oviduct pp 419-444 Ed. ESE Hafez and RJ Blandau. University of Chicago Press, Chicago

Carney EW and Bavister BD (1987) Regulation of hamster embryo development in vitro by carbon dioxide Biology of Reproduction 36 1155-1163

Chatot CL, Ziomek CA, Bavister BD, Lewis JL and Torres I (1989) An improved culture medium supports development of random-bred 1-cell mouse embryos in vitro Joumal of Reproduction and Fertility $86679-688$

Chatot CL, Tasca RJ and Ziomek CA (1990) Glutamine uptake and utilization by preimplantation mouse embryos in CZB medium Journal of Reprodiction and Fertility 89 335-346

Crabtree HG (1929) Observations on the carbohydrate metabolism of tumours Biochemical Joumal 23 536-545

Davis DL (1985) Culture and storage of pig embryos Jounal of Reproduction and Fertility Supplement 33 115-124

Davis DL and Day BN (1978) Cleavage and blastocyst formation by pig eggs in vitro Joumal of Animal Science 46 1043-1053

Day BN (1979) Embryo transfer in swine Theriogenology 11 27-31

Del Monte MA, Rabbani R, Diaz TC, Lattimer SA, Nakamura J, Brennan MC and Greene DA (1991) Sorbitol, myo-inositol and rod outer segment phagocytosis in cultured hRPE cells exposed to glucose. In vitro model of myo-inositol depletion hypothesis of diabetic complications Diabetes $\mathbf{4 0}$ 1335-1345

Ebert KM and Papaioannou VE (1989) In vivo culture of embryos in the immature mouse oviduct Theriogenology 31 299-308

Eppig JJ, Schroeder AC, van de Sand: JJM, Ziomek CA and Bavister BD (1990) Developmental capacity of mouse oocytes that grow and mature in culture: the effect of modification of the protocol Theriogenology 33 89-100

Ellington JE, Camey EW, Farrell PB, Simkin ME and Foote RH (1990) Bovine 1-2-cell embryo development using a simple medium in three oviduct epithelial cell coculture systems Biology of Reproduction 43 97-I04

Eriksson UF, Brolin SE and Naeser P (1989) Influence of sorbitol accumulation on growth and development of embryos cultured in elevated levels of glucose and fuctose Dinbetes Research $1127-32$

Estrada JL, Jones EE, Johnson BH and Petters RM (1991) Effect of insulin-like growth factor-I on protein synthesis in porcine embryonic discs cultured in vitro Joumal of Reproduction and Fertility 93 53-61

Fissore RA, Jackson KV and Kiessling AA (1989) Mouse zygote development in culture medium without protein in the presence of ethylenediaminetetraacetic acid Biology of Reproduction 41 835-841

Flood MR and Wiebold JL (1988) Glucose metabolism by preimplantation pig embryos Jounul of Reproduction and Fertility 84 7-12

French AJ, Zviedrans P, Ashman RJ, Cecil A and Seamark RF (1993) Viability of porcine embryos cultured in simple media Theriogenology 39219 (Abstract)

Galvin JM, Stewart ANV and Meredith S (1993) Higher sodium chloride concentration can induce a four cell block in porcine embryos Theriogenology 39224 (Abstract)

Gardner DK and Lane M (1993) Amino acids and ammonium regulate mouse embryo development in culture Biology of Reproduction 48 377-385
Gardner DK and Leese HJ (1988) The role of glucose and pyruvate transport in regulating nutrient utilization by preimplantation mouse embryos Development 104 423-429

Godkin JD, Bazer FW, lewis GS, Geisert RD and Roberts RM (1982) Synthesis and release of polypeptides by pig conceptuses during the period of blastocyst elongation and attachment Biology of Reproduction 27 977-987

Godkin JD, Bazer FW and Roberts RM (1985) Protein production by cultures established from Day-14-16 sheep and pig conceptuses Jourtal of Reproduction and Fertility 74 377-382

Hagen DR, Prather RS, Sims MM and First NL (1991) Development of one-cell porcine embryos to the blastocyst stage in simple media Jountal of Animal Science 69 I147-I I50

Hamner CE and Fox SB (1969) Biochemistry of oviductal secretions. In The Mammalian Oviduct pp 333-355 Ed. ESE Hafez and RJ Blandau. University of Chicago Press. Chicago

Harney JP, Mirando MA, Smith LC and Bazer FW (1990) Retinol-binding protein: a major secretory product of the pig conceptus Biology of Reproduction 42 523-532

Herrmann HH and Holtz W (1981) Culture of pig embryos collected in situ or after slaughter Animal Reproduction Science 4 143-147

Herrmann $\mathrm{HH}$ and Holtz $\mathrm{W}$ (1985) Storage of pig embryos in the ligated rabbit oviduct and its effect on the viability after re-transfer to synchronized gilts Animal Reproduction Science 8 159-170

Herrmann HH, Schafer B and Holtz W (1981) Collection of two-cell pig embryos and their culture in media containing different protein components Amimal Reproduction Science 4 137-142

Hod M, Star S, Passonneau JV, Unterman TG and Freinkel N (1986) Effect of hyperglycemia on sorbitol and myoinositol content of cultured rat conceptus: failure of aldose reductase inhibitors to modify myo-inositol depletion and dysmorphogenesis Biochemical and Biophysical Research Communications $140974-980$

Holmdahl TH and Mastroianni L, Jr (1965) Continuous collection of rabbit oviduct secretions at low temperature Fertility and Sterility 16 587-595

Illera M], Lorenzo P, Illera JC, Silvan C, Portela A and Petters RM (1992) A simple medium supports in vitro development of one-cell embryos from miniature pigs to the blastocyst stage Theriogenology 37225 (Abstract)

Koobs DH (1972) Phosphate mediation of the Crabtree and Pasteur effects Science 178 127-133

Krisher RL, Petters RM and Johnson BH (1989a) Effect of oviductal condition on the development of one-cell porcine embryos in mouse or rat oviducts maintained in organ culture Theriogenology 32 885-892

Krisher RL, Petters RM, Johnson BH, Bavister BD and Archibong AE (1989b) Development of porcine embryos from the one-cell stage to blastocyst in mouse oviducts maintained in organ culture Joumal of Experimental Zoology 249 235-239

Lawitts JA and Biggers JD (1991a) Overcoming the 2-cell block by modifying standard components in a mouse embryo culture medium Biology of Reproduction 45 245-251

Lawitts JA and Biggers JD (1991b) Optimization of mouse embryo culture media using simple methods jownal of Reproduction and Fertility 91 543-556

Lawitts JA and Biggers JD (1992) Joint effects of sodium chloride, glutamine, and glucose in mouse preimplantation embryo culture media Molecular Reproduction and Development 31 189-194 
Li J, Foote RH and Simkin M (1993) Development of rabbit zygotes cultured in protein-free medium with catalase. taurine, or superoxide dismutase Biology of Reproduction 48 49 33-37

Lindner GM and Wright RW, Jr (1978) Morphological and quantitative aspects of the development of swine embryos in vitro Joumal of Animal Science 46 711-718

Menino AR. Jr and Wright RW, Jr (1982) Development of one-cell porcine embryos in two culture systems Journal of Animal Science 54 583-588

Menino AR, Jr, Archibong AE, Li J-R, Stormshak F and England DC (1989) Comparison of in vitro development of embryos collected from the same gilts at first and third estrus foumal of Animal Science 67 1387-1393

Meyen BA, Rosenkrans CF, Jr and Davis DL (1989) Development of pig blastocysts in vitro is altered by serum, bovine serum albumin and amino acids and vitamins Theriogenology 31 463-471

Miller JGO and Schultz GA (1987) Amino acid content of preimplantation rabbit embryos and fluid from the reproductive tract Biology of Reproduction 37 125-129

Minami N, Bavister BD and Iritani A (1988) Development of hamster two-cell embryos in the isolated mouse oviduct in organ culture system Gamete Research 19 235-240

Minami N, Utsumi K and Iritani A (1992) Effects of low molecular weight oviductal factors on the development of mouse one-cell embryos in vitro Joumal of Reproduction and Fertility $96735-745$

Misener M, Pollard JW and Metzger K (1991) In vitro culture of porcine embryos in CZB medium Theriogenology 35244 (Abstract)

Moore K and Bondioli KR (1993) Glycine and alanine supplementation of culture medium enhances development of in vitro matured and fertilized cattle embryos Biology of Reproduction 48 833-840

Murray FA, Jr, Bazer FW, Rundell JW, Vincent CK, Wallace HD and Wamick AC (1971) Developmental failure of swine embryos restricted to the oviducal environment joumal of Reproduction and Ferilitity 24 445-448

Nakamura J, Del Monte MA, Shewach D, Lattimer SA and Greene DA (1992) Inhibition of phosphatidylinositol synthase by glucose in human retinal pigment cells American Joumal of Physiology 262 E417-E426

Nichol R, Hunter RHF, Gardner DK, Leese HJ and Cooke GM (1992) Concentrations of energy substrates in oviductal fluid and blood plasma of pigs during the peri-ovulatory period Joumal of Reproduction and Fertility 96 699-707

Niemann H, Illera MJ and Driuk PJ (1983) Developmental capacity, size and number of nuclei in pig embryos cultured in vitro Animal Reproduction Science 5 311-321

Papaioannow VE and Ebert KM (1988) The preimplantation pig embryo: cell number and allocation to trophectoderm and inner cell mass of the blastocyst in vivo and in vitro Development 102 793-803

Petters RM (1992) In vitro culture of early stage embryos from livestock Tissue Culture Research Communications 11 305-313

Petters RM and Reed ML (199I) Addition of taurine or hypotaurine to culture medium improves development of one- and two-cell pig embryos in vitro Theriogenology 35 253 (Abstract)

Petters RM, Johnson BH, Reed ML and Archibong AE (1990) Glucose, glutamine and inorganic phosphate in early development of the pig embryo in vitro Journal of Reproduction and Fertility $89269-275$
Powers RD and Tupper JT (1977) Developmental changes in membrane transport and permeability in the early mouse embryo Developmental Biology 56 306-315

Prather RS, Sims MM and First NL (1991) Culture of porcine embryos from the one- and two-cell stage to the blastocyst stage in sheep oviducts Theriogenology 35 1147-1151

Prather RS, Peters MS and Van Winkle LJ (1993) Alanine and leucine transport in unfertilized pig oocytes and early blastocysts Molecular Reproduction and Development 34 250-254

Reed ML, lllera MJ and Petters RM (1992a) In vitro culture of pig embryos Theriogenology 37 95-109

Reed ML, Jin DI and Petters RM (1992b) Glucose and inorganic phosphate inhibits rat 8-cell embryo development in vitro Theriogenology 37282 (Abstract)

Robl JM and Davis DL (1981) Effects of serum on swine morulae and blastocysts in vitro Jounal of Animal Science 52 1450-1456

Rosenkrans CF, Jr, Davis DI, and Milliken G (1989) Pig blastocyst development in vitro is affected by amino acids Jounal of Animal Science 67 1503-1508

Saito $S$ and Niemann H (1991) Effects of extracellular matrices and growth factors on the development of isolated porcine blastomeres Biology of Reproduction 44 927-936

Schini SA and Bavister BD (1988a) Development of golden hamster embryos through the two-cell block in chemically defined medium Jounal of Experimental Zoology 245 111-115

Schini SA and Bavister BD (1988b) Two-cell block to development of cultured hamster embryos is caused by phosphate and glucose Biology of Reproduction 39 1183-1192

Schultz GA, Kaye PL, McKay DJ and Johnson MH (1981) Endogenous amino acid pool sizes in mouse eggs and preimplantation embryos Jownal of Reproduction and Ferfility 61 387-393

Seshagiri PB and Bavister BD (1989a) Glucose inhibits development of hamster B-cell embryos in vitro Biology of Reproduction $40599-606$

Seshagiri PB and Bavister BD (1989b) Phosphate is required for inhibition by glucose of development of harnster 8-cell embryos in vitro Biology of Reproduction 40 607-614

Seshagiri PB and Bavister BD (1991) Glucose and phosphate inhibit respiration and oxidative metabolism in cultured hamster eight-cell embryos: evidence for the 'Crabtree effect' Molecular Reproduction and Developmenl 30 105-111

Sharif H, Lonergan P, Monaghan P, Wahid HA, Gallagher M and Gordon I (1991a) Effect of oviductal condition on the development of early bovine embryos in cultured mouse oviducts Joumal of Reproduction and Fertility Abstract Series 7 Abstract 57

Sharif $H$, Vergos E, Lonergan P, Gallagher $M$, Kinis $A$ and Gordon I (1991b) Development of early bovine embryos in the isolated mouse oviduct maintained in organ culture Theriogenology 35270 (Abstract)

Sharif H, Lonergan P, Monaghan P. Wahid HA, Gallagher M and Gordon I (1992) Development of early bovine embryos in isolated mouse oviducts maintained in organ culture under two gas atmospheres Theriogenology 37297 (Abstract)

Silcox RW and Johnson BH (1988) Developmental potential of day 13 porcine embryonic disk under in vitro culture conditions In Vitro Cellular and Developmental Biology 24 1165-1172

Stone BA, Quinn P and Seamark RF (1984) Energy and protein sources for development of pig embryos cultured beyond hatching in vitro Animal Reproduction Science 7 405-412 
Torres CRL and Rath D (1992) In vitro culture of porcine embryos to the blastocyst stage after in vivo or in vitro fertilization Theriogenology 37283 (Abstract)

Van Winkle Lf (1988) Amino acid transport in developing animal oocyte and early conceptuses Biochimica et Biophysica Acta 947 173-208

Wells KD, Tabbaa MJ and Petters RM (1992) Supplementation of murine embryo culture media with taurine or sorbitol Biology of Reproduction 46 (Supplement 1) 166 (Abstract)

White KL, Hehnke K, Rickords LF, Southern LL, Thompson DL, Jr and Wood TC (1989) Early embryonic development in vitro by coculture with oviductal epithelial cells in pigs Biology of Reproduction 41 425-430

Whitten WK and Biggers JD (1968) Complete development in vitro of the pre-implantation stages of the mouse in a simple chemically defined medium Joumal of. Reproduction and Fertility 17 399-401

Whittingham DG (1968a) Development of zygotes in cultured mouse oviducts. I. The effect of varying oviductal conditions Joumal of Experimental Zoology 169 391-398

Whittingham DG (1968b) Development of zygotes in cultured mouse oviducts. II. The influence of the estrous cycle and ovarian hormones upon the development of the zygote Jounal of Experimental Zoology 169 399-406

Whittingham DG (1968c) Intra- and inter-specific transfer of ova between rat and mouse oviducts Joumal of Reproduction and Fertility 17 575-578

Williams BL, Sparks AET, Canseco RS, Knight JW, Johnson JL, Velander WH. Page RL, Drohan WN, Young JM, Pearson
RE. Wilkins TD and Gwazdauskas FC (1992) In vitro development of zygotes from prepubertal gilts after microinjection of DNA Joumal of Animal Science 70 2207-2211

Wiseman DL, Hendricks DM, Eberhardt DM and Bridges WC (1992) Identification and content of insulin-like growth factors in porcine oviductal fluid Biology of Reproduction 47 126-132

Wollenberg C. Wentz I, Blum B and Holtz. W (1990) Survival of pig embryos flushed from the reproductive tract immediately or two hours after slaughter of donors Joumal of Animal Science 68 2023-2026

Wright RW, Jr (1977) Successful culture in vitro of swine embryos to the blastocyst stage joumal of Animal Science $\mathbf{4 4}$ 854-858

Wu R and Racker E (1959) Regulatory mechanisms in carbohydrate metabolism. Ill. Limiting factors in glycolysis of ascites tumor cells Joumal of Biological Chemistry 234 1029-1035

Youngs CR and MCCinnis LK (1990) In vitro culture of porcine embryos in Whitten's medium containing varying levels of glucose and bovine serum albumin (BSA) Biology of Reproduction 42 (Supplement 1) 58 (Abstract)

Youngs CR, MCGinnis LK and Ford SP (1991) Culture of early pig embryos in medium containing polyvinyl alcohol (PVA) joumal of Animal Science 69 (Supplement 1) 135 (Abstract)

Youngs CR, Ford SP, McGinnis LK and Anderson LH (1993) Investigations into the control of litter size in swine: $\mathbf{l}$. Comparative studies on in vitro development of Meishan and Yorkshire preimplantation embryos joumal of Animal Science 71 1561-1565 